20 Stampfer MJ, Hennekens CH, Manson JE, Colditz GA, Rosner B, Willett WC, et al. Vitamin $\mathrm{E}$ consumption and the risk of coronary heart disease in women. N Engl F Med 1993;328:1444-9.

21 Gey KF, Stahelin HB, Eichholzer. Poor plasma status of carotene and vitamin $\mathrm{C}$ is associated with higher mortality from ischemic heart disease and stroke: Basel prospective study. Clin Investig 1993;71:3-6.

22 Nyyssonen K, Parviainen MT, Salonen R, Korpela H, Tuomilehto J, Salonen JT. Vitamin $C$ deficiency is associated with high risk of myocardial infarction in eastern Finnish men. Eur Heart $f$ 1994;15(suppl): 168.

23 De Lorgeril M, Renaud S, Mamelle N, Salen P, Martin JL, Monjaud I, et al. Mediterranean $\alpha$ linolenic acid-rich diet in secondary prevention of coronary heart disease. Lancet 1994;343:1454-9.

24 Meade TW, Mellows S, Brozovic M, Chakraborti RR, Haines AP, Imeson JD, et al. Haemostatic function and ischaemic heart disease: principal results of the Northwick Park heart study. Lancet 1986;ii:533-7.

25 Wilhelmsen L, Svardsudd K, Korsan-Bengtsen K, Larsson B, Welin L, Tibblin G. Fibrinogen as a risk factor for stroke and myocardial infarction. N Engl F Med 1984;311:501-5.

26 Qizilbash N, Jones L, Warlow C, Mann J. Fibrinogen and lipid concentrations as risk factors for transient ischaemic attacks and minor ischaemic strokes. BMF 1991;303:605-9.

27 Syrianen J, Valtonen VV, livanainen M, Kaste M, Huttunen JK. Preceding infection as an important risk factor for ischaemic brain infarction in young and middle aged patients. BMF 1988;296:1156-60.

28 Spodick DH, Flessas AP, Johnson MM. Association of acute respiratory symptoms with onset of acute myocardial infarction: prospective investigation of 150 consecutive patients and matched control patients. Am Cardiol 1984;53:481-2.
29 Kannel WB, Anderson K, Wilson WF. White blood cell count and cardiovascular disease. JAMA 1992;267:1253-6.

30 Alexander RW. Inflammation and coronary artery disease. $N$ Engl $f$ Med 1994;331:468-9.

31 Akira S, Kishimoto T. IL-6 and NF-IL6 in acute phase response and viral infection. Immunol Rev 1992;127:25-50.

32 Strachan DP. Ventilatory function, height and mortality among lifelong nonsmokers. I Epidemiol Community Health 1992;46:66-70.

33 Marmot MG, Rose G, Shipley M, Hamilton PJS. Employment grade and coronary heart disease in British civil servants. $\mathcal{f}$ Epidemiol Community Health 1978;32:244-9.

34 Wilson TW, Kaplan GA, Kauhanen J, Cohen RD, Wu M, Salonen R, et al. Association between plasma fibrinogen concentration and five socioeconomic indices in the Kuopo ischemic heart disease risk factor study. $\mathrm{Am}$ I Epidemiol 1993;137:292-300.

35 Gregory J, Foster $\mathrm{K}$, Tyler $\mathrm{H}$, Wiseman $\mathrm{M}$. The dietary and nutritional survey of British adults. London: HMSO, 1990:126-52.

36 Khaw KT, Barrett-Connor E. Dietary potassium and stroke associated mortality. N Engl f Med 1987;316:235-40.

37 Khaw KT, Barrett-Connor E. Dietary fiber and reduced ischaemic heart disease mortality rates in men and women: a 12 year prospective study. $A m \mathcal{F}$ Epidemiol 1987;126:1093-102.

38 Gillman M, Cupples L, Gagnon D, Posner B, Ellison R, Castelli W, et al. Protective effect of fruits and vegetables on development of stroke. $A m \mathcal{F}$ Epidemiol 1994;139:S47.

(Accepted 15 May 1995)

\title{
Vitamin C and risk of death from stroke and coronary heart disease in cohort of elderly people
}

\author{
Catharine R Gale, Christopher N Martyn, Paul D Winter, Cyrus Cooper
}

\begin{abstract}
Objectives-To determine whether vitamin C status, as measured by dietary intake and plasma ascorbic acid concentration, is related to mortality from stroke and coronary heart disease in people aged 65 and over.
\end{abstract}

Design-A 20 year follow up study of a cohort of randomly selected elderly people living in the community who had taken part in the 1973-4 Department of Health and Social Security nutritional survey and for whom dietary and other data had been recorded.

Setting-Eight areas in Britain (five in England, two in Scotland, and one in Wales).

Subjects-730 men and women who had completed a seven day dietary record and who had no history or symptoms of stroke, cerebral arteriosclerosis, or coronary heart disease when examined by a geriatrician in 1973-4.

Results-Mortality from stroke was highest in those with the lowest vitamin C status. Those in the highest third of the distribution of vitamin $C$ intake had a relative risk of $0.5(95 \%$ confidence interval 0.3 to 0.8 ) compared with those in the lowest third, after adjustment for age, sex, and established cardiovascular risk factors. The relation between vitamin $C$ intake and stroke was independent of social class and other dietary variables. A similar gradient in risk was present for plasma ascorbic acid concentrations. No association was found between vitamin $\mathbf{C}$ status and risk of death from coronary heart disease.

Conclusion-In elderly people vitamin $\mathrm{C}$ concentration, whether measured by dietary intake or plasma concentration of ascorbic acid, is strongly related to subsequent risk of death from stroke but not from coronary heart disease.

\section{Introduction}

Antioxidant vitamins may be important in protecting low density lipoproteins from oxidation by free radicals. ${ }^{12}$ Because oxidative modification of low density lipoproteins may enhance their atherogenic potential, ${ }^{3}$ dietary antioxidants have a potential role in the prevention of cardiovascular disease. The most important dietary antioxidant in terms of intake is vitamin $\mathrm{C}$, and evidence from ecological studies links low intake of this vitamin with increased rates of cardiovascular disease. In Britain, for example, rates of stroke and coronary heart disease are highest in regions where consumption of fruit and vegetables is lowest. ${ }^{45}$

During 1973-4 the Department of Health and Social Security surveyed random samples of people aged 65 and over living in eight areas of Britain (five in England, two in Scotland, and one in Wales) to assess the nutritional state of the elderly population. The areas were chosen so that the socioeconomic characteristics of the study sample were representative of non-institutionalised elderly people in Britain. We examined the association between vitamin $C$ status, as measured by either dietary intake or plasma ascorbic acid concentration, and mortality from stroke and coronary heart disease in a 20 year follow up study of this national sample.

\section{Subjects and methods}

During 1973 and 1974,1775 people were randomly sampled in eight areas of the country from family practitioner committee lists of all patients aged 65 and over. The areas were Islington, Harrow, Hastings, Bristol, Salford, Rutherglen, Angus, and Merthyr Tydfil. Stratified sampling was used to obtain equal numbers of men and women aged 65 to 74 and 75 and over.

Of those selected, 1688 were living in the community and were asked to take part in the study; 1419 $(84 \%)$ agreed. Of those who participated, $983(69 \%)$ agreed to be examined by a geriatrician $(58 \%$ of those originally selected took part).

Participants kept a diary of every item of food or drink consumed over a week. They were provided with a set of scales to weigh each item. An inteviewer visited them at least four times. If the participants were unable to cope with the weighing procedure, the interviewer used the food diary to quantify their consumption; food purchases were used as a cross check. Nutrient intake was calculated by using a food composition table 
compiled by the Department of Health and Social Security.

The geriatricians measured height, weight, and blood pressure and recorded smoking habits and medication taken in the past six months. A sample of blood was taken for measurement of plasma ascorbic acid and serum cholesterol concentrations. Plasma ascorbic acid was measured by using a spectrophotometric method, a modified version of the procedure originally described by Roe and Kuether. ${ }^{6}$

Of the 983 subjects seen by the geriatrician, all except 12 had usable dietary records. In total 919 (93\%) were traced through the NHS central register. Death certificates were obtained for those who had died, and all causes of death entered in parts I and II were coded according to the International Classification of Diseases (ninth revision). All cases in which either coronary heart disease (codes 410-414) or stroke, excluding subarachnoid and intracerebral haemorrhage, (codes

TABLE I-Median daily intake of vitamin $C(\mathrm{mg})$ by age and sex

\begin{tabular}{|c|c|c|c|c|}
\hline \multirow[b]{2}{*}{ Age (years) } & \multicolumn{2}{|l|}{ Men } & \multicolumn{2}{|l|}{ Women } \\
\hline & $\begin{array}{c}\text { Median } \\
\text { (interquartile range) }\end{array}$ & No & $\begin{array}{c}\text { Median } \\
\text { (interquartile range) }\end{array}$ & No \\
\hline $\begin{array}{l}65-9 \\
70-4 \\
75-9 \\
80-4 \\
\geqslant 85\end{array}$ & $\begin{array}{l}39 \cdot 8(28 \cdot 1 \text { to } 52 \cdot 8) \\
36.5(28.0 \text { to } 53 \cdot 2) \\
36.9(25 \cdot 7 \text { to } 57 \cdot 0) \\
37 \cdot 6(26 \cdot 1 \text { to } 52 \cdot 1) \\
34.3(20.0 \text { to } 39 \cdot 7)\end{array}$ & $\begin{array}{r}86 \\
108 \\
106 \\
62 \\
25\end{array}$ & $\begin{array}{l}36.2(24.5 \text { to } 57.9) \\
37.5(25.8 \text { to } 57.3) \\
32 \cdot 1(22.2 \text { to } 51 \cdot 8) \\
26.4(16.5 \text { to } 41.4) \\
26.9(15.9 \text { to } 43.5)\end{array}$ & $\begin{array}{l}91 \\
88 \\
89 \\
53 \\
22\end{array}$ \\
\hline All & $36.4(27.0$ to 52.3$)$ & 387 & $33.4(21.7$ to 51.0$)$ & 343 \\
\hline
\end{tabular}

TABLE II-Median plasma ascorbic acid concentration ( $\mu$ moll) by age and sex

\begin{tabular}{lcrlll}
\hline & \multicolumn{2}{c}{ Men } & & \multicolumn{2}{c}{ Women } \\
\cline { 2 - 3 } \cline { 5 - 6 } Age (years) & $\begin{array}{c}\text { Median } \\
\text { (interquartile range) }\end{array}$ & No & & $\begin{array}{c}\text { Median } \\
\text { (interquartile range) }\end{array}$ & No \\
\hline $65-9$ & $13.61(9.64$ to 24.38$)$ & 82 & & $26.65(13.61$ to 46.49$)$ & 83 \\
$70-4$ & $15.31(8.51$ to 27.22$)$ & 100 & & $29.48(17.01$ to 47.63$)$ & 82 \\
$75-9$ & $17.01(9.07$ to 30.62$)$ & 96 & & $20.41(12.47$ to 35.72$)$ & 78 \\
$80-4$ & $15.88(9.07$ to 28.92$)$ & 58 & & $11.91(6.80$ to 10.21$)$ & 46 \\
$\geqslant 85$ & $18.14(8.51$ to 24.95$)$ & 23 & & $27.22(18.14$ to 41.39$)$ & 18 \\
\hline All & $15.31(9.07$ to 27.78$)$ & 359 & $22.11(11.91$ to 41.39$)$ & 307 \\
\hline
\end{tabular}

TABLE III-Relative risks of death from stroke according to vitamin $C$ intake, plasma ascorbic acid concentration, and other cardiovascular risk factors. Risks have been calculated for each variable separately and adjusted for age and sex

\begin{tabular}{|c|c|c|c|c|}
\hline Factor & $\begin{array}{c}\text { No of } \\
\text { subjects }\end{array}$ & $\begin{array}{l}\text { No of } \\
\text { deaths }\end{array}$ & $\begin{array}{c}\text { Relative risk } \\
\text { (95\% confidence interval) }\end{array}$ & $\begin{array}{c}\mathbf{P} \\
\text { value }\end{array}$ \\
\hline \multicolumn{5}{|c|}{ Vitamin $C$ daily intake $(\mathrm{mg})$ : } \\
\hline$\leqslant 27.9$ & 244 & 53 & 1 & \\
\hline $28 \cdot 0-44 \cdot 9$ & 243 & 44 & $0.8(0.5$ to 1.2$)$ & \\
\hline$>44.9$ & 243 & 28 & $0.4(0.2$ to 0.6$)$ & $<0.001$ \\
\hline \multicolumn{5}{|c|}{ Plasma ascorbic acid $(\mu \mathrm{mol} / \mathrm{l})$ : } \\
\hline$\leqslant 11.91$ & 226 & 42 & 1 & \\
\hline $11 \cdot 92-27 \cdot 82$ & 229 & 45 & $1.1(0.7$ to 1.7$)$ & \\
\hline$>27.82$ & 211 & 30 & $0.7(0.4$ to 1.1$)$ & 0.012 \\
\hline \multicolumn{5}{|c|}{ Systolic blood pressure $(\mathrm{mm} \mathrm{Hg})$ : } \\
\hline$\leqslant 150$ & 259 & 38 & 1 & \\
\hline $151-175$ & 230 & 35 & $1.0(0.6$ to 1.6$)$ & \\
\hline$>175$ & 225 & 48 & $1.4(0.9$ to 2.2$)$ & 0.004 \\
\hline \multicolumn{5}{|c|}{ Diastolic blood pressure $(\mathrm{mm} \mathrm{Hg})$ : } \\
\hline$\leqslant 80$ & 249 & 33 & 1 & \\
\hline $81-95$ & 242 & 43 & $1.4(0.9$ to 2.3$)$ & \\
\hline$>95$ & 221 & 44 & $1.8(1.1$ to 2.9$)$ & $<0.001$ \\
\hline \multicolumn{5}{|c|}{ Serum cholesterol $(\mathrm{mmol} / \mathrm{l})$ : } \\
\hline$\leqslant 5.43$ & 218 & 49 & $1 \ldots$ & \\
\hline $5 \cdot 44-6 \cdot 28$ & 242 & 34 & $0.5(0.3$ to 0.9$)$ & \\
\hline$>6.28$ & 221 & 32 & $0.5(0.3$ to 0.9$)$ & $<0.001$ \\
\hline \multicolumn{5}{|c|}{ Body mass index $\left(\mathrm{kg} / \mathrm{m}^{2}\right)$ : } \\
\hline$\leqslant 22 \cdot 8$ & 216 & 34 & 1 & \\
\hline $22 \cdot 9-26 \cdot 1$ & 215 & 39 & $1.1(0.6$ to 1.8$)$ & \\
\hline$>26 \cdot 1$ & 217 & 41 & $1.0(0.6$ to 1.7$)$ & $0 \cdot 422$ \\
\hline \multicolumn{5}{|l|}{ Smoking: } \\
\hline No & 459 & 92 & 1 & \\
\hline & 270 & 32 & $0.7(0.5$ to 1.1$)$ & 0.135 \\
\hline \multicolumn{5}{|l|}{ Social class: } \\
\hline Non-manual & 243 & 42 & 1 & \\
\hline Manual & 701 & 74 & $1.1(0.7$ to 1.6$)$ & $0 \cdot 703$ \\
\hline
\end{tabular}

*Because of missing values for some risk factors, numbers of deaths do not always add up to 124 and numbers of subjects do not always add up to 730 .

tCalculated using all variables, except smoking and social class, as continuous.
433-438) were mentioned on the death certificate were counted as deaths from these causes.

A Cox's proportional hazards model was used to examine the associations between risk factors and mortality from stroke or coronary heart disease. Risk estimates were adjusted for sex and age in groups of five years (because of small numbers a 10 year group was used for the oldest age group). The frequency distributions of vitamin $\mathrm{C}$ intake and plasma ascorbic acid concentration were skewed and logarithmic transformations were used when we analysed these as continuous variables. The results are shown as relative risks (hazard ratios) within thirds of the distribution of the variables, with the exception of smoking and social class. $\mathbf{P}$ values were calculated with these variables taken as continuous.

This analysis concerns the 730 subjects who had completed a seven day dietary record and who had no history or symptoms of coronary heart disease, stroke, or cerebral arteriosclerosis when examined by the geriatrician.

\section{Results}

In both men and women vitamin $\mathrm{C}$ intake tended to be lower at older ages. At all ages women had a lower average intake than men (table I). Only 14 subjects took vitamin $\mathrm{C}$ supplements. Average concentrations of plasma ascorbic acid were higher among women but did not vary greatly by age (table II). The correlation coefficient for vitamin $\mathrm{C}$ intake and plasma ascorbic acid concentration was 0.52 . There was no difference between smokers and non-smokers in vitamin $C$ intake, but average plasma ascorbic acid concentration was $21.58 \mu \mathrm{mol} / \mathrm{l}$ in smokers compared with $26.12 \mu \mathrm{mol} / 1$ in non-smokers. Vitamin $\mathrm{C}$ status varied according to social class. Intake among subjects from non-manual classes was $7 \mathrm{mg}$ per day higher than among those from manual classes, and average plasma ascorbic acid concentration was $14.20 \mu \mathrm{mol} / \mathrm{l}$ higher.

\section{STROKE}

During the 20 years of follow up, 643 subjects died. There were 124 deaths from stroke. Mortality from stroke was highest in those who had the lowest vitamin C concentration. Subjects whose vitamin C intake was in the highest third of the distribution had less than half the risk of dying of stroke of those whose intake was in the lowest third. Subjects whose plasma ascorbic acid concentration was in the highest third of the distribution had a relative risk of dying of stroke of 0.7 compared with those in the lowest third (table III). A similar relation between vitamin $\mathrm{C}$ and mortality from stroke was observed in both men and women (data not shown).

Subjects with raised blood pressure had an increased risk of dying of stroke. Those whose diastolic blood pressure was in the highest third of the distribution had nearly double the risk of those in the towest third. Subjects with raised serum cholesterol concentrations had a reduced risk of dying of stroke. Those whose serum cholesterol concentrations were in the upper two thirds of the distribution had a risk of 0.5 compared with those in the lowest third. No association was found between mortality from stroke and body mass index, smoking, or social class. The relation between vitamin $\mathrm{C}$ and mortality from stroke was unaffected by adjustment for diastolic blood pressure and serum cholesterol concentration (table IV). Similar results were obtained when systolic blood pressure was substituted for diastolic pressure.

People who had a higher intake of vitamin $\mathrm{C}$ also tended to have a higher intake of other nutrients. Vitamin C intake was positively correlated with intake of calories, protein, fat, carbohydrate, calcium, iron, 
TABLE IV-Relative risks of death from stroke according to vitamin $C$ intake and plasma ascorbic acid separately adjusted for age, sex, diastolic blood pressure, and serum cholesterol concentration

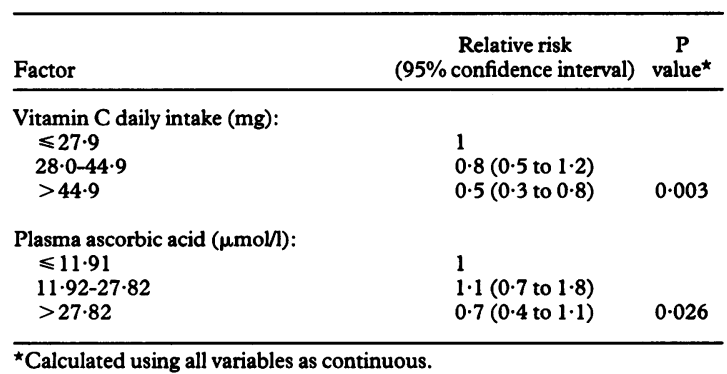

TABLE $\mathrm{v}$-Relative risks of death from coronary heart disease according to vitamin $C$ intake, plasma ascorbic acid concentration, and other cardiovascular risk factors. Risks have been calculated for each variable separately and are adjusted for age and sex

\begin{tabular}{|c|c|c|c|c|}
\hline Factor & $\begin{array}{c}\text { No of } \\
\text { subjects* }\end{array}$ & $\begin{array}{l}\text { No of } \\
\text { deaths }\end{array}$ & $\begin{array}{c}\text { Relative risk } \\
\text { (95\% confidence interval) }\end{array}$ & $\underset{\text { valuet }}{\mathbf{P}}$ \\
\hline \multicolumn{5}{|c|}{ Vitamin C daily intake (mg): } \\
\hline$\leqslant 27.9$ & 244 & $\begin{array}{r}61 \\
50\end{array}$ & & \\
\hline $28 \cdot 0-44 \cdot 9$ & 243 & 59 & $0.9(0.7$ to 1.4$)$ & \\
\hline$>44.9$ & 243 & 62 & $0.8(0.6$ to 1.2$)$ & 0.595 \\
\hline \multicolumn{5}{|c|}{ Plasma ascorbic acid $(\mu \mathrm{mol} / \mathrm{h})$ : } \\
\hline$\leqslant 11.91$ & 226 & 58 & 1 & \\
\hline $11 \cdot 92-27 \cdot 82$ & 229 & 53 & $0.9(0.6$ to 1.3$)$ & \\
\hline$>27.82$ & 211 & 59 & $0.9(0.6$ to 1.3$)$ & 0.520 \\
\hline \multicolumn{5}{|c|}{ Systolic blood pressure $(\mathrm{mm} \mathrm{Hg})$ : } \\
\hline$\leqslant 150$ & 259 & 51 & 1 & \\
\hline $151-175$ & 230 & 61 & $1.6(1.1$ to $2 \cdot 3)$ & \\
\hline$>175$ & 225 & 68 & $1.8(1.2$ to 2.6$)$ & 0.001 \\
\hline \multicolumn{5}{|c|}{ Diastolic blood pressure (mm Hg): } \\
\hline$\leqslant 80$ & 249 & 54 & 1 & \\
\hline $81-95$ & 242 & 63 & $1.4(0.9$ to 2.0$)$ & \\
\hline$>95$ & 221 & 63 & $1.6(1.1$ to 2.4$)$ & 0.006 \\
\hline \multicolumn{5}{|c|}{ Serum cholesterol $(\mathrm{mmol} / \mathrm{l})$ : } \\
\hline$\leqslant 5.43$ & 218 & 46 & 1 & \\
\hline $5 \cdot 44-6 \cdot 28$ & 242 & 65 & $1.3(0.9$ to 1.9$)$ & \\
\hline$>6.28$ & 221 & 57 & $1.2(0.8$ to 1.8$)$ & 0.358 \\
\hline \multicolumn{5}{|c|}{ Body mass index $\left(\mathrm{kg} / \mathrm{m}^{2}\right)$ : } \\
\hline$\leqslant 22 \cdot 8$ & 216 & 45 & 1 & \\
\hline $22 \cdot 9-26 \cdot 1$ & 215 & 58 & $1.2(0.8$ to 1.8$)$ & \\
\hline$>26 \cdot 1$ & 217 & 58 & $1.0(0.7$ to 1.5$)$ & 0.778 \\
\hline \multicolumn{5}{|l|}{ Smoking: } \\
\hline No & 459 & 116 & 1 & \\
\hline Yes & 270 & 66 & $1.0(0.8$ to 1.3$)$ & 0.674 \\
\hline \multicolumn{5}{|l|}{ Social class: } \\
\hline Non-manual & 243 & 61 & 1 & \\
\hline Manual & 458 & 115 & $1.1(0.8$ to 1.8$)$ & 0.598 \\
\hline
\end{tabular}

*Because of missing values for some risk factors, numbers of deaths do not always add up to 182 and numbers of subjects do not always add up to 730 .

†Calculated using all variables, except smoking and social class, as continuous.

retinol equivalents, thiamin, riboflavin, nicotinic acid, pyridoxine, and vitamin $\mathrm{D}$. The analysis was repeated putting each of these variables into the model one at a time with vitamin $C$ intake. Whichever variable was added, vitamin $\mathrm{C}$ remained a significant predictor of mortality from stroke. None of the other dietary variables was related to mortality from stroke independently of vitamin $\mathrm{C}$ intake.

Subjects with symptoms or history of stroke, cerebral arteriosclerosis, or coronary heart disease when examined in 1973-4 were not included in the analysis. It is possible, however, that vitamin C status and serum cholesterol concentration were influenced by other serious illnesses. Blood cholesterol concentrations, for example, may be lowered in patients with cancer, several years before diagnosis. ${ }^{78} \mathrm{We}$ repeated the analysis, firstly excluding all subjects who died during the first two years of follow up and, secondly, excluding all who died in the first 10 years of follow up and whose death certificates contained any mention of cancer. These exclusions had little effect on the association between mortality from stroke and vitamin C; whichever group was excluded, people whose vitamin $\mathrm{C}$ intake was in the highest third of the distribution had a relative risk of 0.5 (95\% confidence interval 0.3 to 0.8 ) compared with those in the lowest third of the distribution, after adjustment for age, sex, diastolic blood pressure, and serum cholesterol concentration. Nor did these exclusions alter the inverse relation between mortality from stroke and serum cholesterol concentration; whichever group was excluded, subjects whose serum cholesterol concentration was in the upper two thirds of the distribution had a relative risk of $0.5(0.3$ to 0.9$)$ compared with those in the lowest third, after adjustment for age, sex, diastolic blood pressure, and vitamin $\mathrm{C}$ intake.

CORONARY HEART DISEASE

There were 182 deaths from coronary heart disease. In contrast with the results for stroke, we found no relation between vitamin $C$ and mortality from coronary heart disease in either men or women, whether analysed separately or together (table V). Subjects with raised blood pressure had an increased risk of dying of coronary heart disease. Those whose systolic blood pressure was in the highest third of the distribution had a risk of 1.8 relative to those in the lowest third, and those whose diastolic blood pressure was in the highest third had a relative risk of 1.6. We found no association between mortality from coronary heart disease and smoking, serum cholesterol concentration, body mass index, or social class.

\section{Discussion}

In this 20 year follow up study of elderly men and women vitamin $C$ status, whether measured by dietary intake or plasma ascorbic acid concentration, was related to risk of death from stroke after adjustment for age, sex, and established cardiovascular risk factors. This association was independent of social class and other dietary variables. Vitamin $\mathrm{C}$ intake was as strongly related to death from stroke as diastolic blood pressure. In contrast, we found no evidence that risk of death from coronary heart disease was related to vitamin $\mathrm{C}$.

One potential weakness in our results comes from the use of mortality data. The known inaccuracies in death certification, particularly in elderly people, may mean that some cases were misclassified. Such misclassification, however, would tend to weaken any association rather than enhance it and to bias estimates of relative risk towards unity. Another possible weakness lies in the assessment of dietary intake of vitamin C. But the relations we found with diet were also present with plasma ascorbic acid concentration. The nutritional survey provided no information on the antioxidants vitamin $E$ and $\beta$ carotene so we could not examine whether these vitamins were associated with mortality from stroke or coronary heart disease. No other dietary variable, however, was related to mortality from stroke independently of vitamin C intake.

Only one prospective study has examined the relation between mortality from stroke and vitamin C. ${ }^{9}$ In 2794 middle aged men in Switzerland those with low plasma concentrations of both ascorbic acid and $\beta$ carotene had four times the risk of dying of stroke. Low concentrations of plasma ascorbic acid alone were not associated with an increased risk. This analysis was based on only 31 deaths from stroke. A prospective study of 11348 people aged 25-74 in the United States reported significantly reduced mortality from all cardiovascular diseases combined among those with a high intake of vitamin $\mathrm{C}$, but there was no analysis of stroke and coronary heart disease separately. ${ }^{10}$

Existing evidence linking coronary heart disease and vitamin C is inconsistent. A 14 year follow up of 5133 Finns aged 30-69 found that a high intake of vitamin C was associated with a reduced risk of death from coronary heart disease in women but not in men. ${ }^{11}$ High intake of vitamin $C$ was also related to a lower risk of coronary heart disease in a prospective study of American women, ${ }^{12}$ but no such relation was observed in a similar study of men. ${ }^{13}$ A prospective study 


\section{Key messages}

- Oxidation of low density lipoproteins may enhance their tendency to cause atheroma

- Vitamin $\mathrm{C}$ is the most important dietary antioxidant in terms of intake

- Both dietary intake of vitamin C and plasma ascorbate concentrations were related to risk of death from stroke (but not from coronary heart disease) in 730 elderly people studied prospectively

- Vitamin C status was as strong a predictor of death from stroke as diastolic blood pressure

- Antioxidant vitamins are potentially important in the prevention of cerebrovascular disease

of middle aged men observed an increased risk of mortality from coronary heart disease in those with low plasma concentrations of both $\beta$ carotene and vitamin $C$, though results for vitamin $C$ alone were not significant. ${ }^{9}$ The range of vitamin $\mathrm{C}$ intakes and plasma concentrations among our elderly subjects may have been too narrow and too concentrated at the lower end of the range to detect any difference in risk of coronary heart disease. In studies in which a significant association was found between low vitamin $C$ status and increased risk of coronary heart disease or cardiovascular mortality, subjects were younger and their average daily intake of vitamin $\mathrm{C}$ was considerably higher. ${ }^{1011}$

The fact that we found no relation between mortality from coronary heart disease and smoking and serum cholesterol concentration may be connected to the age of our subjects. Factors that may predict premature death from coronary heart disease may become less important when measured in a population of elderly survivors. Several studies have shown that the relation between serum cholesterol concentration and mortality from coronary heart disease diminishes with age. ${ }^{14-16}$ In Framingham, the association between cigarette smoking and coronary heart disease disappeared in those aged over $65 . .^{17}$

In other prospective studies in older populations, no relation has been observed between serum cholesterol concentration and risk of stroke. ${ }^{18-20}$ In this study those with raised concentrations of serum cholesterol actually had a reduced risk of dying from stroke. One explanation for this might be that serious illnesses cause cholesterol concentrations to fall. ${ }^{7}$ But we found that the relation was little changed either by the exclusion of all subjects who died in the first two years of follow up or by the exclusion of all subjects who died in the first 10 years of follow up and whose death certificates contained any mention of cancer.

Mortality from stroke has been declining for many decades in Europe and North America. Quantitative assessments have shown that little of this decline can be attributed to pharmacological treatment of risk factors, such as hypertension, or a reduction in case fatality because of better care of acute cases. ${ }^{21}$ One suggestion is that part of the decline in mortality from cardiovascular disease may be due to increased consumption of fresh fruit and vegetables. ${ }^{22}$ Our finding that vitamin C status predicts death from stroke provides support for this hypothesis. Advice to elderly people on health should perhaps emphasise the importance of a high intake of vitamin $\mathrm{C}$.

This research was funded by the Department of Health/ Medical Research Council Nutritional Programme. We thank the Department of Health for allowing us to use data from the 1973-4 DHSS nutritional survey and Clive Osmond of the MRC Environmental Epidemiology Unit for statistical advice. The DHSS survey was coordinated by the late Professor A N Exton-Smith, and the biochemical analyses were carried out by Joan Stephen.

1 Ross R. The pathogenesis of atherosclerosis: a perspective for the 1990 s. Nature 1993;362:801-9.

2 Witztum JL. The oxidation hypothesis of atherosclerosis. Lancet 1994;344:

3 Stringer MD, Gorog PG, Freeman A, Kakkar VV. Lipid peroxides and atherosclerosis. $B M F$ 1989;298:281-4.

4 Armstrong BK, Mann JI, Adelstein AM, Eskin F. Commodity consumption and ischemic heart disease mortality, with special reference to dietary practices. Fournal of Chronic Disease 1975;28:455-69.

5 Acheson RM, Williams DRR. Does consumption of fruit and vegetables protect against stroke? Lancet 1983;i:1191-3.

$6 \mathrm{Roe} \mathrm{JH}$, Kuether CA. The determination of ascorbic acid in whole blood and urine through the 2, 4-dinitrophenyl-hydrazine derivative of ascorbic acid. f Biol Chem 1943;147:399-407.

7 Rose G, Shipley MJ. Plasma lipids and mortality: a source of error. Lancet 1980;i:523-6.

8 Winawer SJ, Flehinger BJ, Buchalter J, Herbert E, Shike M. Declining serum cholesterol levels prior to diagnosis of colon cancer. JAMA 1990;263: 2083-5.

9 Gey KF, Stahelin HB, Eichholzer M. Poor plasma status of carotene and vitamin $C$ is associated with higher mortality from ischemic heart disease and stroke: Basel prospective study. Clin Investig 1993;71:3-6.

10 Enstrom JE, Kanim LE, Klein MA. Vitamin C intake and mortality among sample of the United States population. Epidemiology 1992;3:194-202.

11 Knekt P, Reunanen A, Järvinen R, Seppånen R, Heliơvaara M, Aromaa A. Antioxidant vitamin intake and coronary mortality in a longitudina population study. $A m$ F Epidemiol 1994;139:1 180-9.

12 Manson JE, Stampfer MJ, Willett WC, Colditz GA, Rosner B, Speizer FE, et al. A prospective study of vitamin $\mathrm{C}$ and incidence of coronary heart disease in women. Circulation 1992;85:865 (abstract).

13 Rimm EB, Stampfer MJ, Ascherio A, Giovannucci E, Colditz GA, Willett WC. Vitamin $\mathrm{E}$ consumption and the risk of coronary heart disease in men. N Engl F Med 1993;328:1450-6.

14 Shipley MJ, Pocock SJ, Marmot MG. Does plasma cholesterol concentration predict mortality from coronary heart disease in elderly people? 18 year predict mortality from coronary heart disease in

15 Anderson KM, Castelli WP, Levy D. Cholesterol and mortality. 30 years of follow-up from the Framingham Study. FAMA 1987;257:2176-80.

16 Jajich $\mathrm{CL}$, Ostfeld AM, Freeman DH. Smoking and coronary heart disease mortality in the elderly. FAMA 1984;252:2831-4.

17 Castelli WP, Wilson WF, Levy D, Anderson K. Cardiovascular risk factors in the elderly. Am F Cardiol 1989;63:12-19H.

18 Welin L, Svardsudd K, Wilhelmsen L, Larsson B, Tibblin G. Analysis of ris factors for stroke in a cohort of men born in 1913. N Engl $f$ Med 1987;317 521-6.

19 Khaw KT, Barrett-Connor E, Suarez L, Criqui MH. Predictors of strokeassociated mortality in the elderly. Stroke 1984;15:244-8.

20 Davey Smith G, Shipley MJ, Marmot MG. Plasma cholesterol concentration and mortality. YAMA 1992;267:70-6.

21 Bonita R, Beaglehole R. Explaining stroke mortality trends. Lancet 1993;341: $1510-1$.

22 Verlangieri AJ, Kapeghian JC, El-Dean S, Bush M. Fruit and vegetable consumption and cardiovascular disease mortality. Medical Hypotheses 1985;16:7-15.

(Accepted 24 March 1995)

\section{ONE HUNDRED YEARS AGO}

\section{MATERNAL SUCKLING.}

The Tsaritsa is to be congratulated upon having both the determination and the ability to dispense with the services of wet nurses, and to undertake herself the duty of nourishing her infant daughter. It is said that she is the first Empress of Russia who has ever done so. Fashion is responsible for so much in all that pertains to woman that this event may possibly be life-saving to many infants yet unborn. It no doubt is true that the habits of modern life do unfit a certain number of women for the proper fulfilment of their maternal duties, but there is much reason to believe that the neglect of their infants, which is so common nowadays, is far more often due to fashion than to any real inability to afford them a proper supply of nourishment, and anything which will set the fashion in the direction of more natural methods in the rearing of infants will be of much service in checking the spread of many forms of infantile degeneration.

(BMF 1895;ii:1374.) 